\title{
KEMAMPUAN MENULIS PUISI DENGAN MENGGUNAKAN MEDIA AUDIO-VISUAL SINEMATISASI PUISI SISWA KELAS X SEKOLAH MENENGAH ATAS
}

\author{
Ice Tomatala \\ Elsa Latupeirissa \\ Universitas Pattimura \\ e-mail: tomatalaice@gmail.com
}

\begin{abstract}
Abstrak: Penelitian ini bertujuan untuk mengetahui kemampuan menulis puisi dengan menggunakan media audiovisual sinematisasi puisi. Menulis puisi adalah kegiatan yang menghasilkan karya sastra dengan menuangkan ide dan perasaan penulis. Penulisan puisi dapat dibantu dengan media audio-visual sinematisasi puisi, berupa transformasi puisi menjadi film. Tujuan media tersebut agar siswa memperoleh pengetahuan dan keterampilan dalam menulis puisi dengan baik. Sampel dalam penelitian ini adalah siswa kelas $\mathrm{X}$ Sekolah Menengah Atas. Data penelitian yaitu data kuantitatif berupa aktifitas belajar yang diperoleh melalui observasi secara deskriptif.
\end{abstract}

Kata Kunci: Puisi, Kemampuan Menulis Puisi, Audio-Visual Sinematisasi Puisi. 


\title{
THE ABILITY TO WRITE POETRY USING AUDIO-VISUAL MEDIA POETRY CINEMATIZATION OF $10^{\text {th }}$ GRADE HIGH SCHOOL STUDENTS
}

\author{
Ice Tomatala \\ Elsa Latupeirissa \\ Universitas Pattimura \\ e-mail: tomatalaice@gmail.com
}

\begin{abstract}
This study aims to determine the ability to write poetry by using audio-visual media poetry cinematization. Poetry writing is an activity that produces literary works by expressing the writers idea and feelings. Poetry writing can be helped with audio visualization media poetry in the form of poetry transformation into film. The purpose of the media is for students to gain knowledge and skills in writing poetry well. The sample in this study were $10^{\text {th }}$ grade students of senior high schools. Research data is quantitative data in the form of learning activities obtained through descriptive observation.
\end{abstract}

Keywords: Poetry, Ability To Write Poetry, Audio-Visual Cinematization Poetry 


\section{A. PENDAHULUAN}

Pendidikan merupakan suatu rumpunan ilmu yang mengkaji aktivitas manusia sebagia individu atau kelompok. Pendidikan juga merupakan suatu kegiatan interaksi antara peserta didik dengan para pendidik serta berbagai sumber pendidikan untuk meningkatkan penguasaan pengetahuan dalam rangka pembentukan dan pengembangan diri peserta didik.Ini berarti pendidikan menentukan kemajuan suatu bangsa (Syaodih 2015:2).

Masalah mutu pendidikan termasuk dalam masalah nasional yang dihadapi oleh sistem pendidikan di dalam negara kita (Hamalik, 2007:36). Oleh karena itu pendidik memiliki peran penting dalam meningkatkan mutu pendidikan. Untuk meningkatkan mutu pendidikan, maka diharapkan guru mampu memilih, mencari, menggunakan dan mengembangkan sejumlah metode atau model pembelajaran. Hal ini bertujuan untuk meningkatkan tujuan pembelajaran yang seoptimal mungkin. Metode yang sesuai akan membuat siswa merasa senang dan bersemangat dalam mengikuti kegiatan belajar mengajar di kelas, begitu juga sebaliknya. Metode yang tidak sesuai akan membuat siswa cepat bosan, malas dan tidak bersemangat dalam mengikuti pelajaran.

Media pembelajaran termasuk bagian penting dalam strategi pembelajaran. Secara umum, manfaat media pada pembelajaran untuk memperlancar interaksi pendidik dan peserta didik, dengan tujuan untuk membantu peserta didik dalam pembelajaran secara optimal. Dengan menggunakan media pembelajaran, proses pembelajaran menjadi lebih menarik sehingga dapat meningkatkan motivasi belajar peserta didik. Siswa yang memiliki motivasi belajar kuat akan mempunyai kemampuan untuk melaksanakan kegiatan belajar, begitu pula sebaliknya siswa yang tidak memilliki motivasi belajar maka ia akan bermalas-malasan untuk belajar. Maka dari itu guru mempunyai peran

penting dalam meningkatkan proses belajar mengajar di kelas.

Salah satu upaya peningkatan proses belajar mengajar di sekolah ialah peningkatan keterampilan menulis, seperti membuat puisi. Keterampilan menulis siswa dapat dilakukan dengan menerapkan media pembelajaran, karena media pembelajaran dapat digunakan sebagai media pembelajaran audio-visual.

Penggunaan media audio-visual dapat dikembangkan menjadi media audio-visual sinematisasi puisi. Berkaitan dengan pembelajaran menulis puisi, peserta didik diarahkan untuk menghasilkan sebuah karya yang bisa dinikmati oleh diri sendiri ataupun orang lain. Puisi yang mereka hasilkan berfungsi sebagai sarana yang dituangkan dalam perasaan dan imajinasi ke dalam kata-kata sehingga nantinya akan menjadi sebuah karya tulis yang indah. Hal tersebut sangatlah penting karena pada dasarnya kemampuan siswa untuk mencurahkan ide dan perasaan perlu dilatih dan diberi dorongan. Namun terkadang pembelajaran puisi kurang mendapat perhatian dan cenderung tidak disukai oleh siswa sehingga hal tersebut sangatlah berpengaruh terhadap KKM (kriteria ketuntasan minimal) yang sudah ditentukan.

Berdasarkan wawancara yang telah dilakukan dengan guru mata pelajaran bahasa Indonesia, ibu Suitela di Sekolah Menengah Atas, sebagian siswa kelas X belum memenuhi KKM (70). Faktor penyebeb rendahnya hasil belajar adalah faktor siswa 
sendiri dan gruru. Faktor penyebab siswa sendiri adalah kurangnya pemahaman menulis puisi dan kemampuan siswa mengembangkan ide atau pikiran, serta ketidaktertarikannya media pembelajaran, sehingga siswa belum mampu mengungkapkan diri ke dalam bentuk puisi dengan menggunakan diksi dan pengimajian.

Sehingga dalam penulisan ini lebih difokuskan pada unsur diksi dan pengimajian. Dalam hal ini unsur tersebut merupakan unsur pembangun sebuah puisi, namun bukan berarti mengabaikan unsur lain tetapi untuk lebih berfokus kepada penulisan. Untuk mengatasi masalah tersebut, guru dituntut untuk mendesain model dan media pembelajaran yang sesuai dengan materi yang disampaikan agar membantu siswa lebih memahami materi, membuat siswa lebih aktif, siswa lebih banyak berfikir dan berinteraksi dengan kelas. Cara pengajaran yang mungkin akan diterapkan ketika menjelaskan materi puisi adalah dengan menggunakan media audio-visual.

Media audio-visual yaitu media yang mencakup indera pendengaran dan penglihatan yang dilakukan secara bersamaan. Tujuan pesan disampaikan melalui media bisa berupa pesan verbal dan non verbal seperti media visual dan terdengar seperti media audio. Media ini merupakan kombinasai audio dan visual juga bisa disebut sebagai media pandang-dengar. Media audio-visual dapat dijadikan sebagai penyajian bahan ajar kepada peserta didik secara lengkap dan optimal. Selain itu, media tersebut dapat memiliki batasan tertentu yang menggantikan peran dan tugas pendidik (Munadhi, 2008: 55-57).

Media audio-visual sinematisasi puisi merupakan media yang dipilih oleh peneliti karena bentuk yang dimiliki oleh media tersebut sangat bervariasi. Media audio-visual sinematisasi puisi merupakan perantara atau penggunaan materi dan penyerapan melalui pandangan serta pendengaran, sehingga membangun kondisi yang dapat membantu siswa dan mampu memperoleh pengetahuan serta keterampilan. Hal tersebut merupakan gambaran media sebagai sumber belajar, memberikan suatu alternatif dalam memilih dan menggunakan media pembelajaran yang sesuai dengan karakteristik siswa. Media audio-visual dianggap mampu memberikan motivasi dan minat siswa untuk berprestasi dan termotivasi lebih giat belajar.

Karakteristik media yang dapat dilihat menurut kemampuannya membangkitkan rangsangan seluruh alat indra seperti indera pendengar dan indera penglihatan. Atas dasar itulah peneliti. Karakteristik media merupakan dasar pembelajaran media yang disesuaikan dengan situasi belajar tertentu. Sehingga yang menjadi tujuan penelitian ini adalah untuk mengetahui kemampuan menulis puisi dengan menggunakan media audiovisual sinematisasi puisi siswa kelas $\mathrm{X}$ sekolah menengah atas.

\section{B. PEMBAHASAN}

\section{Kemampuan Menulis}

Menulis sendiri bukanlah sesuatu hal yang asing bagi kita. Ada banyak manfaat yang dapat diambil dari menulis. Manfaat itu diantaranya dalam hal peningkatan 
kecerdasan, pengembangan daya inisiatif dan kreatifitas, penumbuh keberanian serta mendorong kemauan dan kemampuan mengumpuk informasi.namun tidak banyak orang menyukai aktifitas tersebut. Seseorang menulis karena tidak tahu untuk apa dia menulis, merasa tidak berbakat menulis dan merasa tidak tahu bagaimana harus menulis. Ketidaksukaan tidak lepas dari pengaruh lingkungan, keluarga dan masyarakat serta pengalaman pembelajaran menulis atau mengarang disekolah yang kurang memotivasi dan merangsang minat.

Berbicara tentang pengaruh lingkungan di sekolah terkadang masih banyak guru bidang studi bahasa Indonesia yang tidak mampu dalam menulis sebuah karangan sehingga dia kurang memotivasi dan merangsang minat siswa. Pengalaman menulis yang dialami siswa di sekolah tidak terlepas dari kondisi gurunya sendiri. Umumnya gurunya tidak dipersiapkan untuk terampil menulis dan mengajarkannya.

Menulis adalah alat yang saat ampuh dalam belajar yang dengan sendirinya memaninkan peran yang sangat penting dalam dunia pendidikan. Menulis juga merupakan suatu keterampilan bahasa yan dipergunakan untuk berkomunikasi secara tidak langsung, tidak secara tatap muka dengan orang lain. Keterampilan menulis adalah hasil dari keterampilan mendengar, berbicara dan membaca.

Dalam hubungan dengan pengajaran bahasa menulis adalah menggabungkan sejumlah kata menjadi kalimat yang baik dan benar menurut penalaran yang tepat. Menulis adalah pekerjaan yang berdasarkan kemampuan yang diperoleh melalui pengalaman belajar sehingga diperoleh kemampuan yang dapat diaktualisasikan sebagai keterampilan menulis benar-benar dapat diandalkan di kalangan masyarakat maka masyarakat mempercayakan pemberian penyuluhannya kepada guru bahasa. Pengajaran menulis merupakan usaha menghasilkan suatu komponen yang sengaja disiapkan dan dilaksanakan oleh pendidik untuk menghasilkan perubahan tingkah laku sesudah kegiatan instruksional menulis dilaksanakan.

\section{Pengertian Puisi}

Puisi merupakan sebuah karya sastra dengan bahasa yang dipadatkan, dipersingkat dan memiliki irama dengan bunyi yang padu dan pemilihan kata-kata kias (imajinatif). Kata-kata tersebut memiliki arti meskipun singkat dan padat namun berkekuatan.

Pada dasarnya puisi merupakan ungkapan perasaan dan pikiran penulisnya. Sesuatu yang dicurahkan dalam puisi pada hakikatnya merupakan yang dipikirkan atau yang dirasakan oleh penulis sebagai respon mengenai sesuatu yang ada di sekitarnya. Oleh karena itu, pada umumya puisi mempunyai lirik, dan ada juga yang berupa cerita. Puisi bertujuan untuk mengabadikan pengalaman penulis yang dirasakan pada saat itu (Doyin, 2008:1).

Puisi yang di dalamnya terdapat pemikiran untuk membangkitkan perasaan, serta memberikan imajinasi dalam susunan yang berirama. Semua ini termasuk bagian penting, yang terekam serta dinyatakan semenarik mungkin untuk memberi kesan. Puisi juga merupakan rekaman serta hasil interpretasi pengalaman baik seseorang, diubah dalam wujud yang peling berkesan (Mulyana, 1956:112). 


\section{Menulis Puisi}

Menulis puisi pada hakikatnya adalah mengakibatkan apa yang dilihat, dirasakan dan dipikirkannya. Proses pengimajian atau pengembangan lahir dan batin merupakan awal dari proses kreatif.

Pembelajaran pun perlu dilaksanakan secara kontekstual dengan mmenggunakan model, strategi, metode dengan teknik sesuai dengan karakteristik kompetensi dasar agar tujuan pembelajaran tercapai. Materi puisi merupakan salah satu materi pelajaran yang diajarkan untuk memenuhi kurikulum pendidikan. Pembelajaran abad 21 secara sederhana diartikan sebagai pembelajaran yang memberikan kecakapan abad 21 kepada peserta didik yaitu (4C) yang meliputi communication, collaboration critical thinking and problem solving, creative and innovative.

Karakter dalam pembelajaran bertujuan untuk peningkatan mutu pendidikan dalam rangka menjawab tantangan eksternal yaitu globalisasi untuk menunjukan hal tersebut maka guru sebagai ujung tombak pelajaran harus mampu merencanakan dan melaksanakan proses belajar mengajar yang berkualitas. Proses belajar mengajar pada hakekatnya adalah suatu bentuk interaksi antara pihak pengajar dan pelajar yang berlangsung dalam situasi pengajaran dan untuk mencapai tujuan pengajaran. Dalam interaksi itu akan terjadi proses komunikasi timbal balik antara pihak-pihak yang terkait yaitu antara guru selaku pengajar dan siswa selaku pelajar, Surya (2014:333).

\section{Kemampuan Menulis dengan Media Audio-Visual}

Media audio-visual, yaitu media yang selain mengandung unsur suara juga mengandung unsur gambar yang dapat dilihat, seperti rekaman video, berbagai ukuran film, slide suara, dan lain sebagainya. Kemampuan media ini dianggap lebih baik dan lebih menarik, sebab mengandung kedua unsur yaitu pandang-dengar (Sanjaya, 2008:211).

Media gambar sangat cocok untuk membantu siswa meningkatkan kemampuan menulis. Dengan mengunakan gambar siswa dapat berimajinasi kemudian dapat dikembangkan menjadi suatu rangkaian kata sehingga dapat menjadi sebuah karangan yang menarik. Selain mudah dimengerti, juga anak akan terkurangi kejenuhannya. Karena dunia anak adalah dunia visual. Anak lebih mudah paham dengan melihat dari pada mendengar. Melalui gambar ini sedikit demi sedikit kemampuan anak dalam hal menulis akan semakin terasa dan kemampuan anak dalam menulis lambat laun akan menjadi baik.

Sanjaya (2008:40) mengungkapkan Langkah-langkah pembelajaran media audiovisual yaitu:

a. Guru memberikan contoh sebuah puisi.

b. Guru dan siswa mengidentifikasi makna kata yang ada di dalam puisi tersebut.

c. Peserta didik mengamati dan menanyakan tentang contoh puisi yang telah dijelaskan.

d. Guru memvisualisasikan puisi yang telah dijelaskan.

e. Peserta didik mengamati kembali contoh puisi yang telah divisualisasikan. 


\section{Pengertian Media Pembelajaran}

Yunus dalam (Arsyad 1942: 78) perkembangan ilmu pengetahuan yang semakin kompleks menuntut semakin luas pula informasi yang harus disampaikan pada peserta didik. Demikian juga perkembangan teknologi audiovisual dalam proses pengajaran guru tidak lagi mengandalkan benda-benda yang hanya dapat dilihat saja akan tetapi dilengkapi dengan audio sehingga dikenal dengan media audio-visual. Pembelajaran ini tidak hanya memberikan perhatian pada hasil belajar saja, tetapi guru perlu memperhatikan bagaimana aktivitas siswa dalam memecahkan suatu masalah.

Kondisi seperti ini menjadi perhatian dalam pelajaran dan menyebabkan siswa kurang menyenangi dan juga kurang memahami pelajaran bahasa Indonesia secara baik, hakikat belajar bahasa Indonesia tidak cukup mengingat dan menghafal setiap informasi yang didapat. Akan tetapi yang penting adalah bagaimana siswa dapat belajar untuk menemukan informasi yang didapatnya itu dengan belajar melalui semua sumber belajar yang ada. Pada hakikatnya hasil belajar peserta didik disebabkan oleh beberapa faktor dalam diri siswa antara lain bakat, minat, kecerdasan dan kemampuan kognitif. Kemampuan kognitif dalam mata pelajar bahasa Indonesia terkadang mengalami banyak kendala, hal ini dapat dilihat dari kurangnya penguasan tetang konsep dan penggunaan media yang membantu dalam kegiatan pembelajaran.

Tujuan utama dalam proses belajar mengajar adalah mengalihkan sebagian pengetahuan milik guru sehingga pengetahuan itu benar-benar menjadi milik siswa. Cara untuk melaksanakan aliran pengetahuan itu bermacam-macam, namun cara itu bertujuan mencapai penguasaan yaitu agar setiap siswa berhasil menguasai bahan pelajaran yang sesuai dengan patokan yang telah ditetapkan, karena itu bentuk pelaksanaan dengan penyesuaian pada pribadi siswa salah satunya yaitu digunakan media audio-visual. Media audio-visual jelas merupakan media yang dihasilkan dengan teknologi berbasis komputer. Pada hakikatnya teknologi seperti komputer yang menggunakan layar kaca untuk menyampaikan informasi kepada peserta didik.

Menurut Munadhi (2008: 55-57) media pembelajaran digolongkan menjadi beberapa bagian, yaitu:

a. Media audio-visual

b. Media audio

c. Media visual

d. Multimedia

Media dengan pengelolaan teknologi mutakhir meliputi dua jenis. (1) media berbasis telekomunikasi contohnya: mikroprosesor, (2) media berbasis contohnya: komputer dan VCD. Perkembangan teknologi multimedia saat ini telah memasuki aspek kehidupan manusia diberbagai sektor. Seni sastra juga harus mampu beradaptasi dengan selera visualisasi faktual yang tidak asing bagi siswa yang hidup pada zaman modern saat ini. Film merupakan salah satu aplikasi multimedia yang menonjolkan kreasi baru dalam mengungkapkan ide dan gagasan seseorang. Penggunaan media audio-visual sinematisasi puisi ini bertujuan untuk membuat proses pembelajaran lebih 
interaktif, serta sikap positif siswa terhadap proses belajar dapat ditingkatkan sehingga peran guru dapat berubah kearah yang lebih positif dan produktif (Wagiran, 2009:8).

\section{Media Sinematisasi Puisi}

Perkembangan ilmu pengetahuan yang semakin kompleks menuntut semakin luas pula kemajuan teknologi. Salah satunya ialah perkembangan teknologi multimedia yang saat ini telah memasuki aspek kehidupan manusia diberbagai sektor. Seni sastra juga harus mampu beradaptasi dengan selera visualisasi faktual yang tidak asing bagi siswa yang hidup pada era saat ini. Film adalah alat untuk menyampaikan berbagai amanat kepada masyarakat melalui media cerita. Film adalah bagian dari ekspresi yang timbul sebagai suatu kreasi yang dihasilkan oleh para seniman dalam rangka mengutarakan gagasan-gagasan dan ide cerita. Film adalah teater yang dihasilkan secara khusus untuk dipertontonkan di bioskop dan televisi atau sinetron yang dibuat.

Film adalah salah satu yang berkarakteristik masal, yang merupakan kombinasi antara gambar-gambar bergerak dan berkataan. Pegertia sinema dan film adalah cinemathogaphie yang berasal dari cinema dan tho menjadi phito yang berarti cahaya ditambah dengan graphie menjadi tulisan, gambar dan citra jadi pengertian singkat dari sinema adalah lukisan gerak dengan cahaya.

Sinematisasi merupakan istilah yang akhir-akhir ini mulai dipakai dengan kajian sastra Indonesia. Sinematisasi yaitu mengalihkan karya seni dari satu wahana ke wahana yang lain. Dengan demikian secara sederhana dapat dikatakan sinematisasi adalah pengadaptasian karya sastra atau wahana tulis ke dalam film atau wahana audio-visual. Jadi dapat dikatakan bahwa sinematisasi puisi merupakan transformasi puisi menjadi film.

Film adalah alat untuk menyampaikan berbagai pesan kepada khalayak melalui sebuah media cerita. Karya sastra berupa film yang beraliran fiksi akhirnya dinyatakan sebagai kategori karya sastra berdasarkan efek yang dihasilkan bagi penonton, bisa juga film dikategorikan pementasan drama modern yang dapat ditampilkan sebagai pertunjukan utuh yang memenuhi kriteria dari elemen-elemen penting karya fiksi, seperti alur cerita (plot), karakter, seting, prespektif naratif, gaya bahasa, dan pesan yang ingin disampaikan oleh si membuat film melalui transformasi puisi menjadi film ke dalam media audio-visual.

Contoh Puisi yang telah divisualisasikan:

\section{Jendela Perpustakaan}

Langit menyentuh buku-buku pada sore hari

Ketika para pengunjung diminta berhenti membaca

Seorang petugas akan menutupnya dan tidak menyadari pertemuan singkat Mereka yang hangat.Perpisahan dan warna masa kecil itu tiba-tiba musna Orang-orang pulang dengan pikiran lama di kepala 
Lampu-lampu dipadamkan

Buku-buku tidak bisa membaca diri mereka sendiri

Malam akan datang dan kesunyian menyusun dirinya kembali

Di depan perpustakaan langit masi menatap jendela tertutup itu tanpa berkedip...

Aku tidak ingin cepat sampai di rumah

$\mathrm{Ku}$ biarkan langit yang sedih menyentuh kepala ku

Orang-orang tergesah dan tidak membawah buku

Mereka berbahaya dan tidak waspada di jalan menuju rumah

aku ingin memikirkan semua bunyi-bunyian

Bahkan yang paling jauh dan tidak ingin mengerti apa-apa

Di rumah hanya ingin ku renungkan diriku dan seluruh yang tidak inginku lupakan

Jika mimpi datang, aku ingin jadi jendela yang luas untuk langit, buku-buku dan kau....

Karya: Aan Mansyur

\section{KESIMPULAN}

Menulis merupakan salah satu bagian dari pengajaran bahasa Indonesia di sekolah. Pengajaran menulis mempunyai fungsi yang sangat penting untuk melatih siswa dalam mengunakan bahasa Indonesia yang baik dan benar dengan kemampuan menulis siswa diharapkan mampu mengekspresikan berbagai pikiran, gagasan pendapat dan perasaan dalam ragam tulis.

Peningkatan kemampuan menulis bagi siswa kelas $\mathrm{X}$ dapat dikembangkan dalam media audio-visual sinematisasi puisi. Media audio-visual sinematisasi puisi untuk kelas $\mathrm{X}$ dapat digunakan sebagai alternatif media pembelajaran dalam mengembangkan kemampuan menulis puisi bagi siswa kelas $\mathrm{X}$, berdasarkan analisis guru dan siswa membutuhkan media pembelajaran audio-visual sinematisasi puisi yang kemudian diwujudkan dalam bentuk VCD yang berupa puisi yang disinemakan.

Selain itu dengan media audio-visual guru dapat meningkatkan motivasi dan keterampilan siswa dalam menulis puisi hal yang perluh diperhatikan ialah pemilihan tema untuk peserta didik harus disesuaikan dengan umur dan lingkungan siswa.

\section{DAFTAR PUSTAKA}

Arsyad. 2007. Media Pembelajaran. Jakarta: PT Rajagrafindo Persada.

Doyin, M. 2008. Seni Baca Puisi: Persiapan, Pelatihan, Pementasan, dan Penilaian. Semarang: Bandung Institut.

Hamalik O. 2007. Metode Belajar dan Kesulitan-kesulitan Belajar. Bandung: Tasito. Mulyana, S. 1956. Peristiwa Bahasa dan Sastra. Jakarta: Granaco N.V

Munadhi. 2008. Media Pembelajaran Sebuah Pendekatan Baru. Jakarta: Gaung Persada Pers. 
Kemampuan Menulis Puisi dengan Menggunakan Media Audio-Visual Sinematisasi Puisi Siswa Kelas X Sekolah Menengah Atas

Sanjaya, H. W. 2008. Perencanaan dan Desain Sistem Pembelajaran.Jakarta: PT Fajar Interpratama mandiri, Kencana.

Syaodih. 2010. Perencanaan Pengajaran. Jakarta: Rineka Cipta.

Wagiran, M. D. 2009. Bahasa Indonesia Karya Ilmia. Semarang: Universitas Negeri Semarang. 